\title{
SENP1 wt Allele
}

National Cancer Institute

\section{Source}

National Cancer Institute. SENP1 wt Allele. NCI Thesaurus. Code C98062.

Human SENP1 wild-type allele is located in the vicinity of 12 q13.1 and is approximately 63 $\mathrm{kb}$ in length. This allele, which encodes sentrin-specific protease 1 protein, plays a role in both protein desumoylation and the positive regulation of apoptosis. A patient with infantile sacrococcygeal teratoma was found to have a balanced chromosomal translocation $\mathrm{t}(12 ; 15)(\mathrm{q} 13 ; \mathrm{q} 25)$ which fuses this gene and the MESDC2 gene. 